\title{
A Proposed Ethics Code for Online Learning During Crisis
}

\author{
https://doi.org/10.3991/ijet.v16i20.24735 \\ Reham Salhab( $\left.{ }^{\varpi}\right)$, Sherine Hashaikeh, Eman Najjar, Dua’a Wahbeh, Saida Affouneh, \\ Zuheir khlaif \\ An Najah National University, Nablus, Palestine \\ reham.salhabestu.najah. edu
}

\begin{abstract}
The COVID-19 crisis affected the world globally in 2020 and caused school closure around the world, which promptly embraced online learning and raised ethical awareness for teachers and students. Online learning that is based on continuously gaining relevance in educational institutions, is challenged by lack of documented ethics that maintain rights and encourage applying online learning. Unfortunately, online learning ethics are still obscure at this moment. This study aims to propose online code of ethics for Palestinian schools. Applying the mixed methods approach: A focus group with teachers and a questionnaire that was built to explore the teachers' degree of agreement on the proposed online learning ethics. The code was finally being evaluated by online learning experts who have extensive expertise in the field. Results revealed principles of online learning ethics that were highly accepted by school teachers. The researchers recommended conducting future research on the impact of this code on learning and teaching.
\end{abstract}

Keywords —online learning, code of ethics, COVID-19, public school

\section{$1 \quad$ Introduction}

The rapid growth and transformations experienced with information and communication technology provided an evolutionary way of learning since it is easy to find specific information on the internet [1]; [2]. Online learning is one of the outcome tools of recent advancement of technologies; it is based on information and communication technology that supports teaching and learning processes [3] that can be defined as learning eased by technology tools which aims to enhance knowledge retention, skills and productive abilities of learners [4]. These online learning environments enable students to learn flexibly and interact with instructors and other students which makes the teaching -learning process more learner -centered by synchronous and asynchronous environments [5]; [2]. Online learning environments require regulations and policies that balance different expectations of learners and teachers and consider how learners perceive ethics during online learning that is offered [6]. Ethics that have been integrated as an essential dimension of online learning [7]; [8];[9] were considered as attempts to understand humans' behaviors and values, in order to an- 
swer the question of what people should do [10]. Ethical dimensions of online learning focus on issues that aim primarily to cope and support online students' learning [11]. Gudmundsdottir et al. [12] illuminated the necessity to address digital responsibility and digital citizenship responsibility to enhance community participation and content learning.

Online learning ethics are defined as standards and values that must be adhered to in order to achieve the desired human goals, while violating them, is considered an immoral behavior that has many consequences [13]. These ethics should be documented within the code of conduct of the teaching profession for any state, meanwhile, the analysis of the Palestinian code of ethics for teaching profession [14] revealed a lack of online learning ethics, thus, the purpose of the current study was to introduce an online learning code of ethics in the crisis learning environment. Online learning ethics should be present in any educational content, engaging methods, and evaluation tools, as they affect accessing information in an online environment [15]. Ethical considerations can be defined as academic expectations or concerns and gatekeeping considerations to be practiced regardless of the teaching delivery mechanism [16]. Lack of code of ethics will cause lack of engagement interactions among learners due to lack of support from their teachers [4].

\subsection{Statement of problem}

The COVID-19 crisis that swept through the world in general and Palestine particularly in 2020, has forced a digital transformation in teaching and learning. The situation became more complex as ethical issues related to online context began to affect online learning. Nowadays, it has become a necessity to integrate online learning with ethics that maintain teachers and students' rights without harming others or losing their rights [10]; [17]. There is a lack of policy and a nonexistence of code of ethics for online learning in the Palestinian schools and universities. During this crisis, online learning in Palestine went through different issues related to code of ethics that needed to be addressed, documented, and organized. One of the challenges of online learning during crisis is the absence of code of ethics in the Palestinian context. This study is conducted to propose a code of ethics for online learning in the Palestinian schools since it is vital to promote healthy and efficient online environments for both teachers and students [18]; [19]; [20]; [21]; [24]; [25]; [10]. Hence, the problem of this study was stated by proposing a code of ethics for online learning and exploring the degree of teachers' agreement on the proposed ethics in a Palestinian context. The following research questions guided the study:

1. What is the code of ethics for online learning in the Palestinian public schools during crisis?

2. What is the degree of teachers' approval on the proposed code of ethics in online learning during crisis? 


\section{Theoretical Background}

Special interest has grown about ethical issues related to using technology in education, with emphasis on educational ethics during COVID-19 [26],[27]. Numerous problems in society in general surfaced while implementing online learning, issues around ethical assessment of student work and concerns about academic misconduct have been amplified [28]. Ethics are conceptual tools used to assess situations and guide decision-making from an ethical perspective; significantly focus on academic integrity, digital equity and reduced inequality, and digital privacy [29] [30]. There is a lack of existed research that is intended to stimulate ethical values beside cognitive abilities and creativity [25]. Moreover, there is a lack of empirical studies in the area of online learning ethics that has obviously become a concern since it is a neglected topic of research [3]; [33]; [28]. Code of ethics is recommended to contribute in improving the relationships between teachers and students [36].

\subsection{Online learning code of ethics for teachers}

Teachers are responsible for teaching students to be kind, responsible, and respectful, and this should be reflected by their behaviors online. Teachers should be committed to the teaching profession and values and online learning [34] [35]. Moreover, some studies asserted on the importance of the teacher's role in promoting moral development and developing ethical commitment for humanity in an online learning environment by combining ethical with cognitive, social, and emotional aspects [36]; [22]. Academic integrity could be defined as refusing any work without a proper citation [25]. Modeling of good practices by teachers early on academic integrity can mold students' values and attitudes [36].Teachers are responsible to teach digital citizenship effectively, and model ethical technology use for students regularly, they should provide opportunities for equal digital access for learners, help learners in developing their digital literacy skills, teach learners the electronic responsibility for their actions such as stealing identity, downloading illegal resources, hacking others or sending spams or viruses [17]. Moreover, it is the teachers' responsibility to teach students how to use digital media in respectful and safe ways, and how to identify, respond to, and avoid cyber bullying [37]; [10]; [17]). It is the teachers' role to educate students on ethics that control students' behaviors [18]; [38]; [19];[20], [24].; [13].

\subsection{Online learning code of ethics for students}

Students who enrolled in an online learning course should be knowledgeable of its ethics to minimize unethical practices [17]. Academic honesty practice should be taught, addressing ethical issues about intellectual property, plagiarism, copyright and digital privacy issues with students is crucial [31]. Digital privacy is a critical issue on online learning that is related to the electronic transmission of data which can constitute an ethical issue [40]. Learner's digital privacy should not violate since it will affect their learning and engagement processes [40]. Almseidein and Mahasneh [41] 
discussed the necessity of online learning professional code of ethics inclusion in online courses, so students will understand and practice ethical judgments. They also asserted the need for educational institutions to adopt standards, guidelines and ethical policies for an online learning environment for supporting academic rights and roles for both teachers and students. A study conducted by Affouneh [42] focused on taking into consideration ethical issues related to students' privacy which is a topical issue in online learning. A study conducted by Sethy [43] mentioned that a code of ethics will help teachers to be knowledgeable about their responsibilities and to protect them from conducting any unethical actions or behaviors and resolving conflict of interests.

In this study a systematic review of the literature was done for 39 studies related to online learning and digital ethics. In general, code of ethics for both students and teachers could be classified in principles related to the online learning system, rights and responsibilities within the online learning environment.

In this research, code of ethics principles and concepts were revealed by an analytical framework (see figure 1) for categorizing ethical principles to teach online and their responsibilities towards their profession. The Ethical Standards and Standards of Practice for the Teaching Profession framework consists of five dimensions: professional practice, professional knowledge, leadership in learning communities, ongoing professional learning, commitment to students learning. The five dimensions focus on issues such as care, respect, integrity, and trust [44].

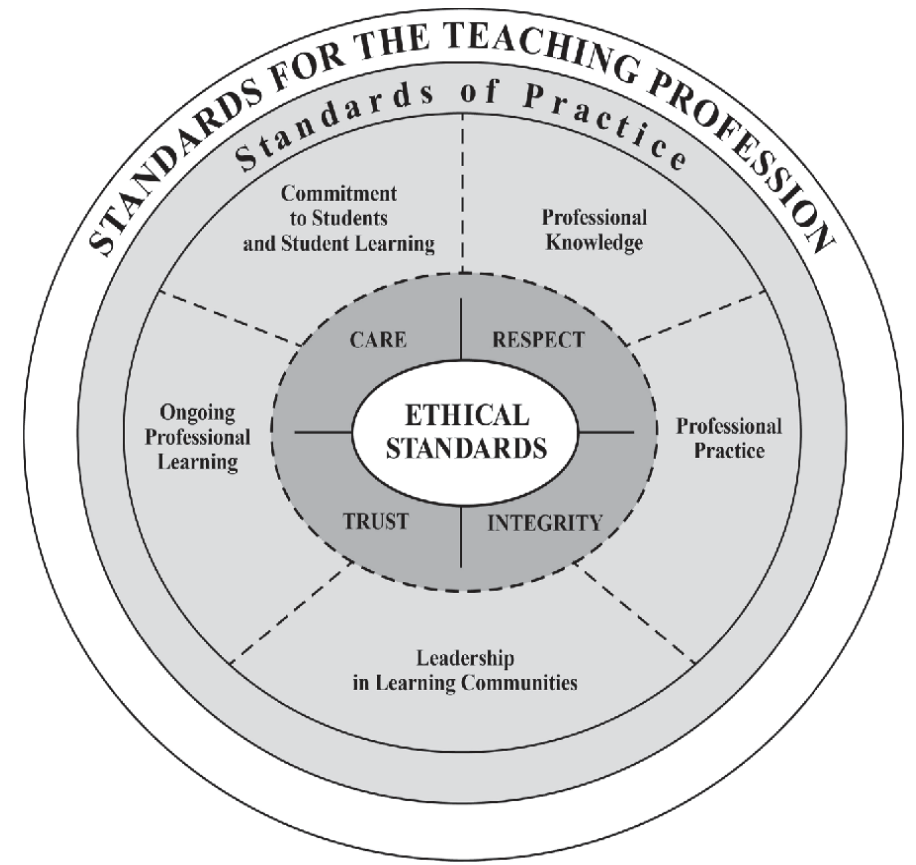

Fig. 1. The Ethical Standards and Standards of Practice for the Teaching Profession (Smith, 2013) 


\section{$3 \quad$ Methodology}

This study applied a mixed methods approach to achieve the purpose of the study [45]. Since the purpose of this study is to suggest an online code of ethics, the researchers used the qualitative approach by using a focus group as a tool to propose and represent principles of code of ethics from teachers' perspectives.

\subsection{Qualitative approach}

A qualitative approach was chosen since it offers a deep understanding of individuals' perceptions; it investigates insights rather than statistical analysis [46]. Data were gathered through focus group discussion, which can provide extensive and diverse information that quantitative research may not often provide; participants can listen to each other's responses which will stimulate new sights to develop their ideas clearly, and to provide in-depth data and prevent misunderstandings [47]. A focus group can be defined as a group of people from similar backgrounds who participate in a discussion about a specific topic with a moderator who introduces the issues to be discussed and make sure no one dominates the discussion and keeps the participants focused on the topic, the data collected in focus group usually relates to participants' values, interactions, thoughts, and experiences with several participants ranges from four to 15 participants [48]. The focus groups sessions were for 120-minute with 10 participants that was conducted through ZOOM. A permission was obtained to record the answers of participants. Teachers who implemented online learning and has taught several classes since the onset of COVID-19 and even before were recruited through an email sent to all these teachers.

Focus group participants. Recruiting the participants in the focus group sessions was based on a convenience sampling procedure [49] was used in selecting participants for focus group as researchers have easy access to these groups of teachers who are willing to participate in the study after obtaining their agreement to participate. The criteria to select these participants was according to the high degree of school implementation of online learning during and before COVID-19. Emails were sent as invitations to participate in the focus group session. The sample consists of 10 teachers (3 males females) from eight public schools from different provinces with at least 5 years' experience. The teachers teach different disciplines from different school levels and they have a good experience with online learning. The focus group started by welcoming and thanking the participants and identifying the goals of the study for them. The prompts of the focus group discussion were derived from the systematic literature review. The study was conducted in an ethical manner; teachers were asked to sign an informed consent form, that explains the and procedures. They were previously informed that participation is not mandatory and that they can withdraw at any time. The participants' names were not declared in the study as part of their privacy; their contact information was hidden in a safe and locked computer [49]. 


\subsection{Quantitative approach}

A Quantitative approach was used in the study collecting and analyzing numerical data to understand opinions, experiences to deepen the insights of a certain problem [45]. The questionnaire as shown in Appendix A was developed depending on the findings of the previous study and the themes emerged from the focus group. The questionnaire included 38 items were grouped in four factors according to the constructs that were found in the systematic literature review and the focus groups: a. commitment to online educational System (9 items) b. Commitment to Profession (8 items) c. Teacher and student rights and responsibilities (10 items) d. Respect and protect digital dignity (11 items). The questionnaire's construct validity was examined by applying the principal component analysis approach. The four factors explain $63.9 \%$ of the total variance. An invitation to participate included a link for the online questionnaire. 250 Participants completed the online questionnaire, but two had to be excluded as they did not complete some questions related to demographics section.

For the participants in the survey, a convenience sample of 250 teachers was selected according to the schools that implemented the online teaching during COVID19 pandemic. The sample were asked to participate in the questionnaire. A convenience sample is a non-probability sampling method that involves selecting a number of individuals who can find them in a specific place and period of time, be available and willing to participate [50].

The teachers who completed the teacher qualification program at the NIET at the $\mathrm{MoE}$ were chosen, due to the availability of researchers within groups on Messenger and WhatsApp, as, due to the COVID-19 pandemic, it was impossible to reach teachers in front of them. The demographic information about the participants in the survey of the sample is shown in Table 1.

Table 1. The characteristics of the study sample

\begin{tabular}{|c|c|c|c|}
\hline Variables & & The number & Percentage \\
\hline \multirow[t]{2}{*}{ Gender } & Male & 40 & $16.1 \%$ \\
\hline & Female & 208 & $83.9 \%$ \\
\hline \multirow{3}{*}{$\begin{array}{l}\text { Experience } \\
\text { teaching }\end{array}$} & Less than 5 years & 52 & $20.8 \%$ \\
\hline & 5- 10 years & 27 & $10.8 \%$ \\
\hline & More than 10 years & 171 & $68.4 \%$ \\
\hline \multirow{5}{*}{$\begin{array}{l}\text { Educational } \\
\text { degree }\end{array}$} & Diploma & 13 & $5.2 \%$ \\
\hline & Bachelor (BA) & 141 & $56.6 \%$ \\
\hline & $\mathrm{BA}+$ certification & 43 & $17.3 \%$ \\
\hline & M.A. & 49 & $19.7 \%$ \\
\hline & $\mathrm{PhD}$ & 3 & $1.2 \%$ \\
\hline \multirow{4}{*}{$\begin{array}{l}\text { Knowledge and } \\
\text { technological } \\
\text { skill }\end{array}$} & very good & 104 & $41.8 \%$ \\
\hline & Weak & 13 & $5.2 \%$ \\
\hline & Average & 90 & $36.1 \%$ \\
\hline & Excellent & 42 & $16.9 \%$ \\
\hline
\end{tabular}


Table 1 shows that most of the respondents were female by (83.9\%), about (68\%) Of the respondents who had experience in education exceeding 10 years, $(57 \%)$ of them hold a bachelor's degree, where approximately $42 \%$ possessed a very good degree of technological knowledge and skills.

\section{Data Analysis}

Thematic analysis was used in analyzing focus group data. Thematic analysis can be defined as a method that is used to analyze, identify and report the patterns (themes) within a text that come up repeatedly. It is flexible and useful research method that provides detailed, and complex data [52]. Analysis of data began with converting the audio files into text responses. The recorded data was heard twice, and transformed into a text that is written; data were classified into themes by two different reviewers. Producing themes and subthemes from the focus group data occurred by the following procedures: responses were read carefully and divided it into small segments and coded accordingly, codes were examined to find common themes that could be created, all focus group data was assigned into tentative themes, all the themes were double checked for accuracy by two reviewers, the final themes were emerged and established [52]. So, the transcripts from focus group comments were analyzed using 'coding' process in which themes are emerging from data set that was identified, organized and classified [47]. By thematic analysis, data were organized into themes, reviewed frequently, then coded continuously to reveal the respondents' feelings, thoughts, perceptions and experiences [53] about certain topics as in the coding book in Table 2 . 
Paper-A Proposed Ethics Code for Online Learning During Crisis

Table 2. A coding book to summarize the themes

\begin{tabular}{|c|c|c|}
\hline Theme & Definition & Example \\
\hline $\begin{array}{l}\text { Commitment to } \\
\text { distance } \\
\text { educational } \\
\text { system }\end{array}$ & $\begin{array}{l}\text { Teachers connecting } \\
\text { with students in } \\
\text { different ways to } \\
\text { support their further } \\
\text { learning. }\end{array}$ & $\begin{array}{l}\text { Teachers must communicate clearly and } \\
\text { frequently with students that will } \\
\text { strengthen their relationship with them }\end{array}$ \\
\hline $\begin{array}{l}\text { Commitment to } \\
\text { profession }\end{array}$ & $\begin{array}{l}\text { Is a process of lifelong } \\
\text { learning and active } \\
\text { participation in the } \\
\text { teaching profession. }\end{array}$ & $\begin{array}{l}\text { In order for teachers to perform their task } \\
\text { properly and professionally, they must } \\
\text { acquire and gain proper technical skills of } \\
\text { the digital world such as planning and } \\
\text { designing and implementing instructional } \\
\text { online content effectively" }\end{array}$ \\
\hline $\begin{array}{l}\text { Teacher and } \\
\text { student rights } \\
\text { and } \\
\text { responsibilities }\end{array}$ & $\begin{array}{l}\text { Teachers and students } \\
\text { have the right to be free } \\
\text { from discrimination as } \\
\text { well as freedom of } \\
\text { expression, privacy, and } \\
\text { religion. }\end{array}$ & $\begin{array}{l}\text { Students will face many problems during } \\
\text { their online engagement such as hacking } \\
\text { their email and social media accounts }\end{array}$ \\
\hline $\begin{array}{l}\text { Respect and } \\
\text { protect dignity }\end{array}$ & $\begin{array}{l}\text { The right of a teacher } \\
\text { or students to be valued } \\
\text { and respected for their } \\
\text { own sake, and to be } \\
\text { treated ethically online. }\end{array}$ & $\begin{array}{l}\text { My colleague experienced bullying from } \\
\text { her students who took her photo from her } \\
\text { personal account and posted it } \\
\text { sarcastically with no responsibility so } \\
\text { ever" }\end{array}$ \\
\hline
\end{tabular}

\subsection{Trustworthiness}

In order to guarantee the trustworthiness of the data analysis and interpretation, first data triangulation was established. Data triangulation was determined through the use of three research tools: systematic literature review, focus group discussion and a questionnaire to increase the external validity of the study by obtaining results from diverse sources of information. For external validity, a questionnaire was used to obtain the results from diverse sources of information to complement the results that were found by focus group. Focus group offers depth of information, while quantitative methods like questionnaire offers a great breadth of information [54].

Second, to ensure consistency a sample of focus group transcripts and their codification were sent to two judges for inter-rater agreement, the agreement between judges was used [54]. The two judges separately transcribed $25 \%$ of the transcription and identified the connections between themes and subthemes. The agreement between judges was .894 which indicated high reliability. Also, the questions of the focus group were sent to two experts in the field and modified according to their recommendations. To analyze the questionnaire collected data, the researchers used the 
SPSS 25 statistical analysis, according to the study questions that required answering descriptive statistics including percentages, median, mean, and standard deviation according to the field as well as the total score. Validity of questionnaire was achieved by three experts and considering their notes in developing it. Reliability was assessed by calculating Cronbach alpha coefficient with a value of 0.94 . Cronbach's Alpha coefficients for each of the subscales were: 0.864 for commitment to distance educational system, 0.816 for commitment to profession, 0.883 for teacher and student rights and responsibilities, 0.911 for respect and protect dignity.

\section{$5 \quad$ Findings}

To answer the first question, a systematic review was done for 39 studies related to online learning and digital ethics. These studies where selected since they discussed the code of ethics in online setting. The results revealed that four topics of online learning ethics were mostly covered in the studies in different ratios as shown in figure (2).

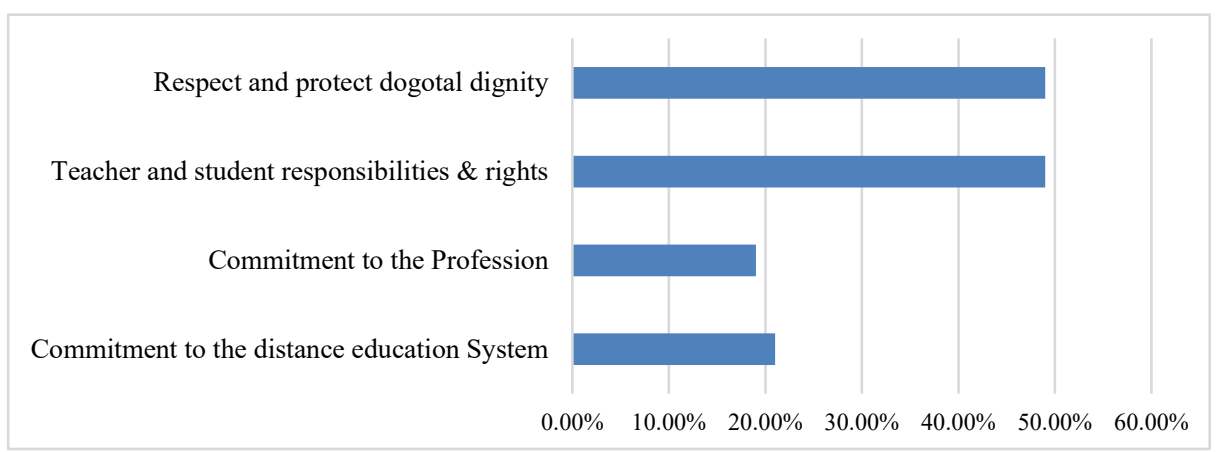

Fig. 2. Figure 2 The percent of reviewed studies covered the topics resulted from online learning ethics systematic review

Also, analysis of data collected from the focus group confirmed these principles for online learning ethics. First principle, commitment to distance education system that includes professional relationships to sustain online learning by maintaining effective online communication with their students and provide continuous feedback and offer assistance for them, cooperating with institution and the parents to maintain internet safety for students, being flexible with students regarding homework submission deadlines if there were any personal or technical problem, being honest, and keep student's information confidential to avoid using technology in violating privacy. Also, this principal includes utilizing media tools to inform students' families about cyber safety (E-safety) awareness that is associated with using online tools to communicate with others, creating a formal professional relationship while interacting with parents to enhance students' learning, and protecting their digital privacy. A teacher said: Teachers must communicate clearly and frequently with students that will strengthen their relationship with them, they need support online, teachers should 
build a rapport with their students, this will lead to a professional healthy online relationship based on mutual respect, and cooperation. Additionally, maintaining professional relationships that will provide a good opportunity to work collaboratively with other teachers in the online community in improving and enhancing online practices, teaching strategies, and exchange thoughts and ideas on how to solve common problems associated with online learning, avoiding underestimating technical illiterate student or colleagues, and try to assist them to improve their knowledge and skills and try to offer help when needed, so everyone has something to learn from others. A teacher mentioned: "I never looked down at my collogues technical skills, on the opposite I tried to support them whenever I could ".

The second principle is about teachers' and student's rights and responsibilities to sustain effective online learning. Teachers should help learners in developing their digital literacy and technical skills and feel responsible towards their own learning process by consistently motivating and encouraging them. A teacher said: We are so concerned that students will face many problems during their online engagement such as hacking their email and social media accounts, harming their bodies by excessive Internet usage, using some people's data to ridicule and sharing it abusively, and wrongly using of some videos, therefore, students need guidance and emotional support from there to be aware of how to protect their accounts and use security settings. This principal also includes paying close attention to special needs students and offering help when they need it.

The third principle is the commitment to the profession. Teachers should always try their best to improve their digital literacy and technical skills that includes attending assigned online workshops, training programs, watching instructional videos to help them design, and assess online learning activities and proper assessment tools. These issues were mentioned by a teacher who said: In order for teachers to perform their task properly and professionally, they must acquire and gain proper technical skills of the digital world such as planning and designing and implementing instructional online content.

The fourth principle is respect and digital dignity protection within online learning. Teachers adopted online learning as a result of digital transformation in education due to the pandemic, thus, teachers need support from policy makers and their academic institutions to protect teacher's and student's digital dignity. Moreover, digital dignity related to cyber bullying and gender stereotypes should be avoided for both students and their teachers. It is vital to respect teachers and motivate them continuously.

The findings of the questionnaire aim to answer the second question of the study: What is the degree of teachers' approval on the proposed code of ethics?

We examined the relationship between the degree of respondents' approval of the code of ethics for online learning with demographic variables, a T-test was used for independent samples to examine the relationship with the teacher gender variable, and for the rest of the demographic variables only, the ANOVA test was used. The degree of respondents' four principles that were extracted from the focus group analysis is shown below in Table 3 . 
Paper-A Proposed Ethics Code for Online Learning During Crisis

Table 3. The degree to which respondents agree to the ethical standards of online learning.

\begin{tabular}{llcc}
\hline Topic & Mean & SD & $\begin{array}{c}\text { Degree of } \\
\text { agreement }\end{array}$ \\
\hline$\quad$ Commitment to distance educational & & 8.06 & High \\
System & 82.8 & & \\
$\quad$ Commitment to Profession & 85.69 & 8.13 & High \\
$\quad$ Teacher and student rights and & 87.32 & 8.75 & High \\
responsibilities & 89.534 & 9.79 & High \\
$\quad$ Respect and protect digital dignity & 86.35 & 7.38 & High \\
\hline Tot. Degree & & & \\
\hline
\end{tabular}

Table 3 shows that there is a high degree agreement from teachers on each of the proposed topics and on the total online learning ethics.

An independent-samples t-test was conducted to test the differences in teachers' degrees of agreement regarding gender. There were no significant differences between males and females in their agreement on each of these principles: commitment to the distance education System, $\mathrm{t}(246)=1.103, \mathrm{p}=.271$, commitment to profession, $\mathrm{t}(246)=-.201, \mathrm{p}=.841$, teachers' and students' rights and responsibilities, $\mathrm{t}(246)=$ $.102, \mathrm{p}=.919$, and Respect and protect digital dignity $\mathrm{t}(246)=-.739, \mathrm{p}=.461$. Thus, we accept the null hypothesis.

A one-way ANOVA was conducted to test the differences between teacher's agreement on each of the proposed online learning principles regarding demographic characteristics. Table 4 showed that there is no statistically significant difference between teachers' degree of agreement in regarding to years of experiences nor to their educational qualification. On the other hand, there are statistically significant differences at the $\mathrm{p}<.05$ in the degrees of agreement for each of the online learning proposed principles regarding teachers' technological skills.

Table 4. Results of ANOVA test for the differences between teachers' degrees of agreement regarding to demographic characteristics

\begin{tabular}{|l|l|l|c|c|c|c|}
\hline & & & $\begin{array}{c}\text { Commitment to } \\
\text { the distance edu- } \\
\text { cation System }\end{array}$ & $\begin{array}{c}\text { Commitment to } \\
\text { the Profession }\end{array}$ & $\begin{array}{c}\text { Teacher and } \\
\text { student re- } \\
\text { sponsibilities }\end{array}$ & $\begin{array}{c}\text { Respect and } \\
\text { protect digital } \\
\text { dignity }\end{array}$ \\
\hline \multirow{3}{*}{$\begin{array}{l}\text { Degree of } \\
\text { knowledge } \\
\text { and techno- } \\
\text { logical skill }\end{array}$} & \multirow{2}{*}{ Mean } & Good & 90.35 & 88.58 & 86.54 & 84.6 \\
\cline { 2 - 7 } & low & 87.69 & 84.77 & 80.77 & 70.8 \\
\cline { 2 - 7 } & Foderate & 87.86 & 84.49 & 83.97 & 79.4 \\
\cline { 2 - 7 } & F. Good & 91.73 & 91.29 & 88.93 & 89.6 \\
\hline & Sig & 2.976 & 9.044 & 4.993 & 22.5 \\
\hline
\end{tabular}

Therefore, a Scheffe's post hoc test was conducted and showed that the differences were due to the very good level in technological skills. For respect and protect digital dignity principle, differences between very good, good, moderate and low skills of technology were statistically significant in favor of the very good level that had the 
highest mean, differences between good moderate and low skills of technology were statistically significant in favor of the good level that had the highest mean, and differences between moderate and low skills of technology were statistically significant in favor of the moderate level that had the highest mean.

\section{Discussion}

The current findings provide evidence to adopt a code of online learning ethics. The systematic review of 39 reviewed studies showed that the main principles of online learning are teachers' rights and responsibilities in addition to respect and digital dignity. The researchers believe that these principles are among the most important issues related to online learning, which are discussed in many studies from different aspects that ultimately lead to the central point related to the online learning environment. Our findings indicated that awareness of ethical principles helps in creating a healthy environment and ensuring high-quality professional standards for online learning, this supports Barak and Green [4] findings.

The findings from focus group and questionnaire analysis matched principles of systematic review and the theoretical framework model [44]. This indicates the importance of these ethical principles as resulted in the current study that was implemented in the Palestinian context, in addition to their global importance as addressed by many international studies from various regions of the world, which means that these ethical principles are the most important due to their impact on online learning and its continuity, whereas ethical principles are clearly useful in evaluating situations and guiding decision-making from an ethical perspective by focusing on ethical values, including digital equity and digital privacy, which are shared by many people from different places and cultures as mentioned in previous studies [29], [30].

Also, the results confirmed the importance of online code of ethics for both teachers and students, thus researchers propose four online learning ethical principles: respect and protect digital dignity, commitment to the profession, commitment to the distance educational system, teachers' and students' rights and responsibilities within an online learning environment. These principles conquer with many studies previously [31]; [32]; [33]; [1]. These principles asserted on the importance of rights and duties for both teachers and students within online environment as mentioned in several studies [18]; [19]; [20]; [21]; [22]; [23]; [24];[13]. Respect and protecting digital dignity are one of human rights that should be respected and treated without any discrimination. Researchers found that ensuring the safety of human elements in all their physical, psychological and intellectual aspects achieves the required goals that guarantees effective online learning which supports previous study [17].Commitment to profession and distance education system could provide important principles to maintain digital academic honesty, integrity, dignity, and mutual respect and to fulfill of the obligation to the profession without discrimination on the basis of race, color, marital status, age, or handicapping condition which matches results of previous studies [34] [33]; [35]. Additionally, online learning values that include the values of cooperation, mutual trust, respect for diversity, individual differences and varying 
capabilities, so that each party can perform its duty comfortably and without fear or embarrassment [9].

High agreement percentage of teachers that resulted from the questionnaire on the four proposed principles confirmed their importance, however there were differences in the degree of agreement due to technological competencies where teachers with higher technological capabilities accepted online learning ethics more than those with lower technological skills as they know and practice more the online learning, thus teachers should be trained on online learning in order to increase their engagement to develop their technological knowledge (Reimers et al., 2020).

\section{Conclusion and recommendations}

The current study proposed ethical principles to be included in a code of online learning ethics that aim at providing disciplinary guidelines and principles for selfdiscipline in online environment, building a strong ethical foundation for achieving an online learning, defining the duties and responsibilities of teachers towards themselves, their profession, students and society in order to sustain online learning and obtaining community confidence in supporting online learning. The proposed online code of ethics that was developed as a result of this study consists of the following components. It started by the introduction which describes the background of code of ethics and the necessity for having it, then the goals for having developing this code, followed by glossary and terminology and then the four ethical principles: respect and protect digital dignity and privacy, commitment to the distance education system, commitment to the profession, and teachers' and student's rights and responsibilities. The rights and responsibilities of teachers and students were discussed at the end of the document, the following link is for the designated proposed code of ethics: https://docs.google.com/document/d/1thfHsotv7UuuOM9HvDDgldTmEptz6o7G3dqq 9HML14k/edit?usp=sharing

The code of ethics was developed in two languages Arabic and English and discussed through a national workshop in order to disseminate. The researchers are working now on designing it as a booklet to be sent to all formal educational institutions in Palestine. Finally, results of this study were used to develop online code of ethics for both teachers and students that help to provide a safer online environment, therefore, researchers recommend the followings: reflect on the proposed code of ethics and included principles in order to adopt it, share the online learning code of ethics with all teachers in order to know their rights and duties. Code of ethics outlines the teacher's main responsibilities to their students and defines their roles to help them enhance the learning process and make it more efficient, train teachers in online learning ethics and the needed technological skills, conduct future research on the impact of this code on learning and teaching. 


\section{References}

[1] Yıldız, E. P.; Çengel, M.; Alkan, A. Determination of Digital Citizenship Levels of University Students at Sakarya University Turkey. International Journal of Higher Education, 2020 ,9(3),300-308. https://doi.org/10.5430/ijhe.v9n3p300

[2] Singh, V., Thurman, A. How many ways can we define online learning? A systematic literature review of definitions of online learning (1988-2018). American Journal of Distance Education, 2019, 33(4), 289-306. https://doi.org/10.1080/08923647.2019.1663082

[3] Kebritchi, M.; Lipschuetz, A.; Santiague,L. (2017). Issues and challenges for teaching successful online courses in higher education: A literature review. Journal of Educational Technology Systems, 16(10), 4-29. https://doi.org/10.1177/0047239516661713

[4] Barak, M.; Green, G. (2020). Novice Researchers' Views About Online Ethics Education and the Instructional Design Components that May Foster Ethical Practice. Sci Eng Ethics, 26, 1403-1421. https://doi.org/10.1007/s11948-019-00169-1

[5] Dhawan, S. (2020). Online learning: A panacea in the time of COVID-19 crisis. Journal of Educational Technology Systems, 49(1), 5-22. https://doi.org/10.1177/0047239520934018

[6] Alabbasi, D. Exploring Teachers Perspectives towards Using Gamification Techniques in Online Learning, TOJET: The Turkish Online Journal of Educational Technology, 2018, 17 (2), 34-54. https://doi.org/10.17718/tojde.328951

[7] García-Peñalvo, F. J. Reference model for virtual education at face-to-face universities. Campus Virtuales, 2020, 9(1), 41-56. https://doi.org/10.5281/zenodo.3937537

[8] Toprak, E.; Özkanal, B.; Aydin, S. Ethics in e- learning, The Turkish Online Journal of Educational Technology ,2010, (2),78-86. https://files.eric.ed.gov/fulltext/EJ898005.pdf

[9] Khan, B. Managing e-learning strategies: design, delivery, implementation and evaluation (USA, Hershey PA), 2005. https://doi.org/10.4018/978-1-59140-634-1

[10] Farrow, R. A Framework for the Ethics of Open Education. Open Praxis, 2016, 8(2), 93109. https://files.eric.ed.gov/fulltext/EJ1103941.pdf

[11] Gudmundsdottir, G. B.; Hathaway, D. M. " We Always Make It Work": Teachers' Agency in the Time of Crisis. Journal of Technology and Teacher Education, 2020, 28(2), 239250. https://www.learntechlib.org/primary/p/216242/

[12] Al-Abdullatif, A., and Azza G. (2020) "Exploring students' knowledge and practice of digital citizenship in higher education. "International Journal of Emerging Technologies in Learning (iJET) 15, no. 19: 122-142. https://doi.org/10.3991/ijet.v15i19.15611

[13] Rose, E. Beyond social presence: Facelessness and the ethics of asynchronous online education. McGill Journal of Education, 2017, 52(1), 17-32. https://doi.org/10.7202/1040802ar

[14] MOHE. Ethics of the teaching profession and codes of conduct, Palestine: Education Development Authority, 2010. https://doi.org/10.25304/rlt.v28.2308

[15] Satterfield D.; Kelle S. (2017) Ethical Issues in Online Education. In: Ahram T., Karwowski W. (eds) Advances in The Human Side of Service Engineering. Advances in Intelligent Systems and Computing, vol 494. Springer, Cham. https://doi.org/10.1007/978-3$\underline{319-41947-3 \quad 24}$

[16] Sheperis, D. S.; Ordway, A.; Lamar, M. Legal and Ethical Challenges in Online Counselor $\begin{array}{llll}\text { Education. } & \text { Professional } & \text { Counselor, 2020, 10(1), }\end{array}$ https://doi.org/10.15241/dss.10.1.106

[17] Saputra, M., Al Siddiq, and Imamul H. (2020). "Social Media and Digital Citizenship: The Urgency of Digital Literacy in the Middle of a Disrupted Society Era. "International Journal of Emerging Technologies in Learning 15(7). https://doi.org/10.3991/ijet.v15i07.13239 
[18] Balyer, A.; Özcan, K. Choosing Teaching Profession as a Career: Students' Reasons. International Education Studies, 2014, 7(5), 104-115. https://doi.org/10.5539/ies.v7n5p104

[19] Etherington, M. Pride in Education: A Narrative Study of Five Finnish Schoolteachers Experience and Their Perception of Professional Ethics: Postulating a Model. (2019). International Journal of Instruction, 11(4), 257-270. https://doi.org/10.1177/2158244019845489

[20] Cornali, F. I'm going to be a teacher! exploring motives for teaching of a sample of preprimary and primary teacher candidates. Education 3-13, 2019, 47(5), 570-588. https://doi.org/10.1080/03004279.2018.1510426

[21] Mark, K.; Nguyen, T. An Invitation to Internet Safety and Ethics: School and Family Collaboration. Journal of Invitational Theory and Practice ,2017, 23, 62.-75. https://files.eric.ed.gov/fulltext/EJ1184559.pdf

[22] Ng. Alvin; Vighnarajah F. S; Chuah, K. M. Ethical conduct of e-teachers in online learning community. Pakistan Journal of Distance and Online Learning, 2017, 3(2), 01-12.

[23] Fray, L., Gore, J. Why people choose teaching: A scoping review of empirical studies, 2007-2016. Teaching and Teacher Education, 2018, 75, 153-163. https://doi.org/10.1016/j.tate.2018.06.009

[24] Khan, I. A. Ethical considerations in an educational research: a critical analysis. Journal of Education, Society and Behavioral Science, 2016, 1-8. https://doi.org/10.9734/BJESBS/2016/21821

[25] Yamamoto, J.; Ananou, S. Humanity in the Digital Age: Cognitive, Social, Emotional, and Ethical Implications. Contemporary Educational Technology, 2015, 6(1), 118. https://doi.org/10.30935/cedtech/6136

[26] Schrading, W. A.; Pigott, D.; Thompson, L. Virtual Remote Attending Supervision in an Academic Emergency Department during the Covid-19 Pandemic. AEM Education and Training, 2020, https://doi.org/10.1002/aet2.10460

[27] Archambault, L.; Borup, J. Coming Together as a Research Community to Support Educators and Students in k-12, Online and Emergency Remote Settings. Journal of Online Learning Research, 2020, 6, 1-3.

[28] Alshehri, Y.; Mordhah, N.; Alsibiani, S.; Alsobhi, S.; Alnazzawi, N. How the Regular Teaching Converted to Fully Online Teaching in Saudi Arabia during the Coronavirus COVID-19. Creative Education, 2020, 11, 985-996. https://doi.org/10.4236/ce.2020.117071

[29] Aldosemani, T. Towards Ethically Responsive Online Education: Variables and Strategies from Educators' Perspective. Journal of Education and Learning, 2020, 9(1), 79-86. https://doi.org/10.5539/jel.v9n1p79

[30] Toprak, E.; Özkanal, B.; Aydin, S. Ethics in e- learning, The Turkish Online Journal of Educational Technology ,2010, (2),78-86. https://files.eric.ed.gov/fulltext/EJ898005.pdf

[31] Burbidge, T., \& Hamer, R. (2020). Academic Honesty in the International Baccalaureate Diploma Programme: Student, Teacher, and School Perspectives. Journal of International Students, 2020, Vol 10 (2), 10(2), 265-285. https://doi.org/10.32674/jis.v10i2.667

[32] Wright, S. L.; Katz, J. A. Protecting student intellectual property in the entrepreneurial classroom. Journal of Management Education, 2016, 40(2), 152-169. https://doi.org/10.1177/1052562915622665

[33] Maxwell, B., (2017). Codes of Professional Conduct and Ethics Education for Future Teachers, Philosophical Inquiry in Education, 24(4). 323- 347. https://doi.org/10.7202/1070690ar

[34] Moses, I.; Admiraal, W.; Berry, A.; Saab, N. (2019). Student-teachers' commitment to teaching and intentions to enter the teaching profession in Tanzania. South African Journal of Education, ,9(1). 115. https://doi.org/10.15700/saje.v39n1a1485 
[35] Mutambik, I. The Role of e-Learning in Studying English as a Foreign Language in Saudi Arabia: Students' and Teachers' Perspectives. English Language Teaching, 2018,11(5), 7483. https://doi.org/10.5539/elt.v11n5p74

[36] Stoesz, B.; Yudintseva, A. Effectiveness of tutorials for promoting educational integrity: a synthesis paper. International Journal for Educational Integrity, 2018, 14(1), 1-22. https://doi.org/10.1007/s40979-018-0030-0

[37] Jesús, M.; Torres, N.; Pessoa, T. Competence of future teachers in the digital security area, Communication Media Education Research Journal, 2019, 61. 53-62. https://doi.org/10.3916/C61-2019-05

[38] Bušíková, A.; Melicheríková, Z. Ethics in E-Learning. International Association for Development of the Information Society. Proceedings of the IADIS international conference on e-learning, 2013, (435-438). Prague. https://files.eric.ed.gov/fulltext/ED562272.pdf

[39] Khlaif, Z. N.; Salha, S. The Unanticipated Educational Challenges of Developing Countries in Covid-19 Crisis: A Brief Report. Interdisciplinary Journal of Virtual Learning in Medical Sciences, 2020, 11(2), 130-134.

[40] Almseidein, T; Mahasneh, O. Awareness of Ethical Issues when using an e-Learning System. International Journal of Advanced Computer Science and Applications, 2020, 11(1).128-131. https://doi.org/10.14569/IJACSA.2020.0110116

[41] Affouneh S; Salha S; Khlaif ZN. Designing Quality E-Learning Environments for Emergency Remote Teaching in Coronavirus Crisis. Med Sci, 2020, 11(2):1- 3. https://doi.org/10.30476/IJVLMS.2020.86120.1033

[42] Sethy, S. S. Academic ethics: Teaching profession and teacher professionalism in higher education settings. Journal of Academic Ethics, 2018, 16(4), 287-299. https://doi.org/10.1007/s10805-018-9313-6

[43] Smith, D. M. (2013). A Dialogic Construction of Ethical Standards for the Teaching Profession. Issues in Teacher Education, 2013, 22(1), 49-62.

[44] Creswell, J. W. (2014). Research design: Qualitative, quantitative, and mixed methods approaches. Thousand oaks: SAGE Publications.

[45] Silverman, D. (2005). Doing Qualitative Research. London: Sage Publications.

[46] Xerri, D. (2018). The use of interviews and focus groups in teacher research. The Clearing House: A Journal of Educational Strategies, Issues and Ideas, 2020, 91(3), 140-146. https://doi.org/10.1080/00098655.2018.1436820

[47] Krueger, R. A. Focus groups: A practical guide for applied research. Sage publications, 2014. https://doi.org/10.2307/3172912

[48] Ngozwana, N. (2018). Ethical Dilemmas in Qualitative Research Methodology: Researcher's Reflections. International Journal of Educational Methodology, 4(1), 19-28. https://doi.org/10.12973/ijem.4.1.19

[49] Etikan, I.; Musa, S. Alkassim, R. (2016). Comparison of convenience sampling and purposive sampling. American journal of theoretical and applied statistics, 5 (1), 1-4. https://doi.org/10.11648/j.ajtas.20160501.11

[50] Braun V., Clarke V. Using thematic analysis in Reimers, F., Schleicher, A., Saavedra, J., \&Tuominen, S. (2020). Supporting the continuation of teaching and learning during the COVID-19 Pandemic.

[51] Khlaif, Z. N. (2018). Factors influencing teachers' attitudes toward mobile technology integration in K-12. Technology, Knowledge and Learning, 23(1), 161-175. https://doi.org/10.1007/s10758-017-9311-6

[52] Ugur, N.G. Digitalization in higher education: A qualitative approach. International Journal of Technology in Education and Science (IJTES), 2020, 4(1), 18-25. ISSN: 2651-5369. https://doi.org/10.46328/ijtes.v4i1.24 
[53] Adanan, H., Mahdum A., and Tutut H. (2020) "M-WebQuest development: reading comprehension of senior high school students in Indonesia." International Journal of Emerging Technologies in Learning (iJET) 15(3): 74-92. https://doi.org/10.3991/ijet.v15i03.10628

\section{Authors}

Reham Salhab is PhD candidate at An Najah National university (NNU). She is a college instructor; she has published articles on the effect of Interactive smart board in a microteaching environment and implementing Moodle for college students.

Sherine Hashaikeh is a Ph.D. student at program of learning and teaching at AnNajah National University. M.A in Educational Administration at (ANNU). She is a school Principal in Nablus.

Eman Najjar is a manager of the research department in the Center for Educational Research \& Development (CERD) in Palestine, a PhD candidate from (ANNU). She has published several researches in international journals.

Dua Wahbeh' is a $\mathrm{PhD}$ candidate from ANNU, a head of the training section in NIET (the National Institute of Educational Training), and a certified trainer for teachers from the Ministry of Education, Massachusetts university, and Cambridge university.

Saida Affouneh is an Associate Professor at An Najah National University who works as the Dean of Faculty of Educational sciences and Teacher Training and Director of e-learning center, has a $\mathrm{PhD}$ in education in emergency situation. she has won many local and International Awards in excellence in teaching and learning.

Zuheir khlaif is a lecturer at An Najah National University. His research interest is in technology integration, STEM. COMPUTATIONAL Thinking and MOOC. Khlaif works as a consultant for establishing Afghan Virtual University

Article submitted 2021-06-12. Resubmitted 2021-08-06. Final acceptance 2021-08-07. Final version published as submitted by the authors. 